\title{
СОСТАВ И СТРУКТУРА МАКРОЗООБЕНТОСА МАЛЫХ ОЗЕР В ЗОНЕ ВЛИЯНИЯ МЕДНО-НИКЕЛЕВОГО КОМБИНАТА
}

\section{Валькова С.A.}

Институт проблем промышленной экологии Севера, обособленное подразделение КНЦ РАН, Anamumbl,valkova@inep.ksc.ru

Комбинат «евероникель»КольскойГМК-крупнейшеепредприятиегорно-металлургического комплекса Мурманской области, являющееся главным источником загрязнения поверхностных вод региона тяжелыми металлами [1].

Многолетняя антропогенная нагрузка предприятия на пресноводные экосистемы привела к серьезным преобразованиям их структуры и накоплению значительных количеств загрязняющих веществ в донных отложениях и на территории водосбора. Основными источниками поступления тяжелых металлов в водоемы вблизи комбината «Североникель» являются процессы аэротехногенного загрязнения, подземный и поверхностные стоки, ремобилизация металлов из донных отложений.

Большинство гидробиологических исследований в зоне влияния комбината «Североникель» посвящены крупнейшему водоему Мурманской области - озеру Имандра (в частности, губе Монче), также имеются сведения о макрозообентосе оз. Нюд-явр $[2,9,10,6,1]$. Сведения о составе и структуре макрозообентоса малых водоемов в зоне влияния комбината «Североникель» отсутствуют.

Озеро Нюд-явр является самым крупным внутренним водоемом Мончегорского района с площадью водосбора 90.54 км², занимает впадину с заболоченными берегами к северу от окружающих его сопок Монче-тундры, и располагается непосредственно между городом Мончегорск и промплощадкой АО «Кольская ГМК». Водоем разделен дамбой на северную и южную части. Южная часть представляет собой технологический отстойник, который служит приемником сильнозагрязненных сточных вод предприятия, из него по трубам перетока частично очищенные воды поступают в северную часть водоема. На водосборной площади оз. Нюд-явр расположены озера Кумужье, Сопчъявр, Травяное и Пыслысчимъявр.

В 2016-17 гг. проводилось изучение состава и структуры макрозообентоса озер Нюд-явр, Кумужье, Сопчъявр, Травяное и Пыслысчимъявр, также исследованы сообщества макрозообентоса, развивающиеся в районе труб перетока, связывающих отстойник и основную часть акватории оз. Нюд-явр.

Отбор и анализ проб зообентоса проводили согласно ГОСТ 17.1.3.07-82, с использованием рекомендованных стандартных методик $[5,8]$. Пробы донных отложений из глубоководной зоны водоемов отбирали с помощью дночерпателя Экмана-Берджа с площадью захвата грунта $290 \mathrm{~cm}^{2}$, на литорали отбирали качественные пробы с помощью гидробиологического сачка-скребка Сарбера. Отборы качественных и количественных проб зообентоса были проведены в конце гидробиологического лета (август) во всех выбранных озерах, на каждом водоеме отобрано по 3 пробы из глубоководной части и зоны литорали.

\section{Гидрохимическая характеристика исследованных водоемов}

В природном состоянии реакция среды водоемов Кольского полуострова нейтральная [1]. Придонные слои воды исследованных озер, за исключением оз. Нюд-явр имели нейтральную реакцию (табл. 1). Поступление слабо очищенных сильнощелочных сточных вод в северную часть оз. Нюд-явр привело к повышению рН придонных слоев воды и смещению реакции среды в сторону щелочной.

Насыщение растворенным кислородом регистрировалось в диапазоне от 10 до 70\%. В июле и августе с повышением температуры воды и усилением интенсивности поглощения кислорода донными отложениями содержание кислорода не превышало 4 мг/дм³.

Минерализация вод озер находилась в диапазоне от 47.2 до 65.9 мг/дм³ , что выше значений, характерных для природных поверхностных вод Кольского полуострова (20-30 мг/дм³). По соотношению главных ионов воды исследованных водоемов относятся к сульфатно-гидрокарбонатному (оз. Кумужье, Травяное), сульфатному (оз. Пыслысчимъявр), гидрокарбонатно-сульфатному 
(оз. Сопчъявр) и хлоридно-сульфатному (оз. Нюд-явр). В природном состоянии поверхностные воды региона относятся к классу гидрокарбонатов [1].

По содержанию биогенных элементов озера характеризуются как олиготрофные. Во всех исследуемых водоемах отмечаются повышенные концентрации никеля и меди в воде, что обусловлено влиянием аэротехногенных выбросов комбината «Североникель». Таким образом, по основным гидрохимическим показателям, среди исследованных водоемов озеро Кумужье можно характеризовать как наименее подверженный антропогенной трансформации водоем.

Таблица. 1. Гидрохимические показатели исследованных водоемов.

(придонные слои воды, в числителе - среднее за 2015-2017 гг., в знаменателе - $\min$ - max).

\begin{tabular}{|c|c|c|c|c|c|}
\hline Показатели & оз. Кумужье & оз. Травяное & оз. Пыслысчимъявр & оз. Сопчъявр & $\begin{array}{l}\text { оз. Нюдъявр } \\
\text { (сев. часть) }\end{array}$ \\
\hline pH, ед. & $7.0 \frac{7.0}{0-7.0}$ & $6 \frac{7.0}{6.7-7.2}$ & 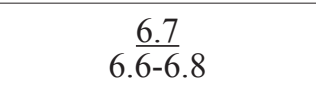 & $7 . \frac{7.2}{0-7 . \underline{3}}$ & $8 . \frac{9.0}{3-10.2}$ \\
\hline Кислород, мг/дм³ & $3 . \frac{4.1}{1-5.3}$ & $1.1-8.7$ & $4 . \frac{6.7}{4-9.4}$ & $3.9-4.6 .3$ & $2 . \frac{5.3}{2-6.7}$ \\
\hline 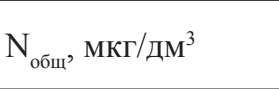 & $\frac{133}{55-252}$ & $\frac{270}{198-396}$ & $\frac{183}{145-241}$ & $\frac{233}{171-348}$ & $\frac{610}{178-1280}$ \\
\hline 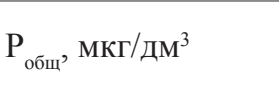 & $\frac{12}{5-21}$ & $\frac{16}{13-21}$ & $\frac{6}{4-7}$ & $\frac{12}{6-21}$ & $2 \frac{45}{1-83}$ \\
\hline $\begin{array}{l}\text { Органическое } \\
\text { вещество, мг/дм³ }\end{array}$ & $2.4-1.5$ & $4.7-8.2$ & $4 . \frac{4.5}{2-4.8}$ & $2.2 .4-2.5$ & $4 . \frac{4.8}{0-5.2}$ \\
\hline $\begin{array}{l}\text { Минерализация, } \\
\text { мг/дм }\end{array}$ & $30-145$ & $5 \frac{57}{54-60}$ & $4 \frac{50}{6-57}$ & $\frac{86}{46-150}$ & $90 \frac{1932}{2-3777}$ \\
\hline $\mathrm{Na}^{+}, \mathrm{мг} /$ дм$^{3}$ & $\frac{2.5}{1.3-4.7}$ & $4.0-\frac{4.8}{4-6.1}$ & $\frac{1.8}{1.7-2.1}$ & $7.8-34.2$ & $27 \frac{660}{7-1360}$ \\
\hline $\mathrm{Cu}$, мкг/дм ${ }^{3}$ & $\frac{15}{10-22}$ & $13 \frac{164}{1-218}$ & $\frac{81}{61-92}$ & $\frac{39}{18-63}$ & $8 \frac{112}{2-168}$ \\
\hline $\mathrm{Ni}$, мкг/дм ${ }^{3}$ & $\frac{109}{48-206}$ & $12 \frac{189}{1-253}$ & $209-320$ & $21 \frac{341}{4-590}$ & $\frac{220}{165-296}$ \\
\hline Со, мкг/дм³ & $0 . \frac{3.4}{4-8.4}$ & 2.6 .0 & $2 \frac{31}{22-38}$ & $\frac{7.8}{3.5-14.5}$ & $3.7-4.9$ \\
\hline
\end{tabular}

\section{Характеристика сообществ макрозообентоса}

Концентрация тяжелых металлов в воде и донных отложениях - лимитирующие факторы для большинства бентосных беспозвоночных. В токсической среде резко сокращается видовое разнообразие, как всех донных беспозвоночных, так и относительно устойчивых к тяжелым металлам видов. Из всех систематических групп в воде с высокими концентрациями $\mathrm{Ni}$ и $\mathrm{Cu}$ обнаруживались лишь нематоды, хирономиды, полужесткокрылые, ручейники и вислокрылки. Среди личинок хирономид наиболее устойчивы к действию тяжелых металлов представители сем. Orthocladiinae (Psectrocladius, Cricotopus), они являются частыми обитателями загрязненных водоемов и водотоков [12]. Ручейники, обнаруженные в наиболее загрязненных водоемах, принадлежат к семействам Polycentropodidae и Rhyacophilidae. Мизиды, бокоплавы, нимфы поденок и веснянок, пиявки и моллюски чувствительны к тяжелым металлам, в водоемах с высокой токсической нагрузкой, как правило, не встречаются $[4,11]$.

Для исследованных малых водоемов характерен обедненный видовой состав макрозообентоса и крайне низкие уровни численности и биомассы донных беспозвоночных. Основу бентосной фауны большинства исследованных водоемов составляли хирономиды, другие группы беспозвоночных были малочисленны. В озере Сопчъявр макрозообентос был представлен только единичными экземплярами хиромид рода Psectrocladius, в озере Травяном отмечены немногочисленные хирономиды родов Polypedilum (Pentapedilum) и Procladius. В озере Пыслысчимъявр, которое расположено в непосредственной близости от Мончегорской площадки Кольской ГМК донные организмы не обнаружены. 
В донных отложениях глубоководной зоны озера Нюд-явр. единично отмечены только личинки широко распространенных в пресноводных водоемах субарктической зоны, устойчивых к загрязнению тяжелыми металлами хирономид вида Procladius (Holotanypus) choreus gr. Значительно выше разнообразие бентосной фауны, развивающиеся в районе труб перетока, связывающих отстойник и основную часть акватории озера. Здесь зарегистрированы хирономиды родов Psectrocladius, Glyptotendipes, Procladius, Cricotopus и Orthocladius, доминировали в составе сообществ личинки Psectrocladius, субдоминантом были приуроченные преимущественно к водноосоковыми сообществами представители рода Cricotopus. Также встречались хищники - водные клопы гребляки (Sigara sp.) и клопы-водомерки (Gerris sp.).

В составе макрозообентоса озера Кумужье зарегистрированы 4 таксономические группы беспозвоночных ранга семейств и отрядов: ручейники Polycentropus flavomaculatus Pictet, 1834, хирономиды Procladius (Holotanypus) choreus gr., преобладающие в составе хирономидных сообществ, Chironomus sp., Polypedilum (Pentapedilum) sp., личинки двукрылых сем. Rhagionidae и Dolihopodidae и амфиподы Gammarus lacustris Sars, 1863. По составу макрозообентоса озеро Кумужье наиболее близко к водоемам незагрязненных районов северотаежной зоны Мурманской области [6].

Таким образом, сообщества макрозообентоса исследованных водных объектов развиваются в условиях токсификации, что обуславливает обедненный видовой состав и низкий уровень численности и биомассы донной фауны. Наиболее близки к естественно-природному состоянию бентосные сообщества оз. Кумужье.

Трофический статус всех исследованных водных объектов оценивается как олиготрофный, что в значительной степени обусловлено воздействием на водоемы аэротехногенных выбросов металлургического комбината, способствующих процессам «олиготрофизации» вод в результате общего замедления биопродкуционных процессов в токсической среде. Степень загрязненности вод по ГОСТ 17.1.3.07-82 озер Травяное и Сопчъявр оценивается как «очень грязные»; озеро Нюд-явр - «грязные», озеро Кумужье - «умеренно-загрязненные».

\section{Литература}

1. Антропогенные модификации экосистемы озера Имандра /под ред. Т.И. Моисеенко/ М.: Наука. 2002. 403 с.

2. Антропогенные преобразования водных экосистем Кольского Севера / Т.И. Моисеенко, В.А. Яковлев. Л.: Наука. 1990. 219 с.

3. Валькова С.А., Кашулин Н.А., Даувальтер В.А., Сандимиров С.С. Структура и динамика сообществ зообентоса оз. Большая Имандра в зоне влияния медно-никелевого комбината // Тр. КНЦ РАН 3/2012 (10). Прикладная экология Севера. Изд-во КНЦ РАН. 2012. Вып. 2. С. $22-39$.

4. Горкин И.Н. Рыбы и бентос как индикаторы загрязнений речных и эстуарных экосистем лососевых рек тяжелыми металлами // Экологические аспекты химического и радиоактивнго загрязнения водной среды. Москва. 1983. С. 68-79.

5. Методическое руководство по биотестированию воды. РД 118-0290. Москва. 1991. 48 с.

6. Пресноводный зообентос северной Фенноскандии (разнообразие, структура и антропогенная динамика) /В.А. Яковлев/. Апатиты: Изд-во КНЦ РАН. 2005. Ч. 1. 161 с.

7. Пресноводный планктон в токсичной среде / Л.П. Брагинский, И.М. Величко, Е.П. Щербань/. Киев. Изд-во: Наукова Дум. 1987. 180 с.

8. Руководство по гидробиологическому мониторингу пресноводных экосистем. С.-Пб. Гидрометеоиздат. $1992.320 \mathrm{c}$.

9. Яковлев В.А. Воздействие тяжелых металлов на пресноводный зообентос: Ч. 1. Бионакопление // Экологическая химия. 2002 а. № 11(1). С. 27-39.

10. Яковлев В.А. Воздействие тяжелых металлов на пресноводный зообентос: Ч. 2. Последствия для сообществ // Экологическая химия. 2002 б. № 11(2). С. 117-132.

11. Biological Indicatorsof Freshwater Pollution and Envirinment management / J.M. Hellawell. London-New York. 1986. $546 \mathrm{p}$.

12. Pinder L.C.V. Biology of freshwater Chironomidae // Ann. Rev. Entomol. 1986. V. 31. P. 1-23. 